\title{
Imagens de sedução na pedagogia. "A sedução como estratégia profissional"*
}

\author{
Clermont Gauthier \\ Stéphane Martineau"
}

\begin{abstract}
Resumo: Este texto tem por objetivo responder a uma questão por muito tempo oculta em educação, a saber, se é possível pensar a sedução como uma estratégia profissional na relação pedagógica. Para tanto, analisamos seis figuras de grandes sedutores da literatura: Sócrates, Casanova, Dom Juan, Valmont, Johannes e Xerazade. Essa análise permitiu compreender que se a sedução, às vezes, está relacionada com o engodo, por outro lado, ela está longe de ser sempre negativa. Dessa maneira, depreendem-se algumas características de uma sedução positiva, isto é, identificamse condições de um uso ético da sedução no ensino.
\end{abstract}

Palavras-chave:Sedução, jogo, relação pedagógica, trabalho interativo, ética

Muitas outras coisas precisariam ser retomadas, matizadas, mas já é tempo de ir aos fatos, depois de termos simplesmente lembrado esta evidência: não há ser totalmente alheio à sedução. Mesmo aqueles que a recusam parecem estremecer diante dessa recusa.

(Sibony 1986, p. 18)

\section{Introdução}

Sedução na pedagogia? A expressão causa espanto. Ou meIhor, escandaliza. "Como é possível imaginar que uma coisa tão per-

\footnotetext{
* Texto traduzido por Francisco Pereira de Lima.

** Respectivamente: Universidade de Laval e Universidade de Toronto.
} 
versa como essa esteja ocorrendo, na surdina, em nossas salas de aula?" Como é possível afirmar que os professores lançam mão de um procedimento tão baixo? E, no entanto, pensando bem, a sedução é algo que seduz. Passados os primeiros momentos de resistência, cada um de nós reconhece que lança mão desse recurso quando ensina (Lafon 1992). Nessa reação está expresso todo o equívoco relativo a esse conceito. A sedução deixa as pessoas sem graça porque representa, de certo modo, o engodo, o mal, a imoralidade e, evidentemente, a culpa. Mas a sedução é também uma necessidade, e até mesmo um doce prazer. Ora, admitir não poder deixar de fazer uso de alguma coisa e, ao mesmo tempo, só ver nisso corrupção, é condenar-se a deixar esse objeto num intervalo da consciência, é não agir sobre a sedução, mas deixá-la agir sobre si. O objetivo deste texto é refletir sobre esse problema controverso. A posição que adotamos aqui não é normativa: não reprovamos a sedução nem fazemos sua apologia. De uma maneira mais pragmática, constatamos a presença incontornável da sedução nas relações humanas e, por conseguinte, na pedagogia. O texto analisa o exercício desse "poder velado, latente, inconfessado e 'melhor', mais agradável para todo o mundo... que tem mesmo a ver com o prazer" (Lafon 1992, p. 166). Ele tenta responder a uma pergunta que, durante muito tempo, permaneceu oculta: é possível imaginar a sedução como uma estratégia profissional na relação pedagógica? Na tentativa de encontrar uma resposta, analisamos seis imagens de grandes sedutores da literatura: Sócrates, Casanova, Dom Juan, Valmont, Johannes e Xerazade. Essa análise nos dará a possibilidade de mostrar que, se a sedução, às vezes, tem a ver com o engodo, nem tudo nela é negativo. Nesse sentido, identificaremos certas características de uma sedução positiva, propondo, desse modo, algumas pistas interessantes que nos ajudarão a refletir sobre as condições que possibilitam o uso ético da sedução no ensino.

\section{Ensinar é jogar}

Como toda relação social, o trabalho docente é semelhante a um jogo. Na verdade, nas relações interpessoais, "os indivíduos empregam o que se poderia chamar de estratégias de ganho" (Goffman 1988, p. 100). A interação pode ser vista, desse modo, "como uma série de 
dribles e de contradribles entre jogadores profissionais" (Winkin apud Goffman 1988, p. 67). Cada gesto, cada palavra, cada atitude é como uma jogada no tabuleiro das relações sociais.

Como se sabe, todo jogo de salão comporta uma série de características - tais como regras, protagonistas, desafios, relações de força, uma dinâmica complexa -, nas quais o ensino se enquadra e que convém examinar brevemente.

As regras - A análise de Durand (1996) mostra certos limites da situação pedagógica que impõem uma determinada organização do trabalho docente. Esses limites atuam como regras e estruturam os comportamentos do professor. Por exemplo, os objetivos do sistema de educação e dos níveis de ensino são definidos por documentos oficiais. Além do mais, esses objetivos são especificados em programas de ensino e organizados, na maioria das vezes, em torno das disciplinas escolares, algumas das quais são mais importantes do que outras. Nesse sentido, o tempo atribuído a esses diversos campos do saber escolar é calculado com precisão e varia conforme o bloco ao qual pertence cada disciplina: português e matemática têm mais horas do que educação artística ou educação física. Além disso, a duração do ensino é de mais ou menos dez meses, e as crianças, cuja presença na escola é obrigatória, são divididas em grupos durante esse período de tempo. Aliás, a classe ou turma não designa somente a natureza do grupo (classe da primeira série, classe de português), mas também o espaço geográfico, isto é, o local onde os alunos se encontram. Essa arena determina igualmente o comportamento dos atores que aí se encontram, tanto por sua delimitação fechada quanto pelos objetos materiais que contém: mesas, carteiras, computadores, quadros etc.

Os protagonistas - Nesse contexto, os atores, alunos e professor entram numa espécie de jogo chamado também de "trabalho interativo". Para Cherradi, o trabalho interativo caracteriza-se por colocar "indivíduos-trabalhadores ou grupos de trabalhadores em relação com um objeto de trabalho que é feito não de matéria inerte, mas de outros indivíduos-usuários ou de outros grupos humanos" (1990, p. 4). Esse tipo de atividade apresenta, assim, a particularidade de agir diretamente sobre o ser humano. Cherradi identificou três tipos de trabalho interativo. O primeiro está relacionado com as interações de apoio, que visam "prever, interromper ou retardar a deterioração do bem-estar de uma pessoa ou de sua condição social" (1990, p. 18). 
Nesse tipo de interação, que caracteriza especialmente o trabalho médico, no qual a racionalidade instrumental é mais forte, a interação é reduzida ao mínimo, e o usuário, reduzido praticamente ao estado de objeto, torna-se particularmente dependente; até a sua colaboração só é necessária em parte. No segundo tipo de trabalho interativo, a tarefa se resume principalmente a um conjunto de transações que ocorrem entre o trabalhador interativo, o usuário e a pasta deste último. Nesse tipo de interação, chamado de interação de atribuição, a legislação desempenha um papel preponderante e aparece, na maioria das vezes, como um recurso facilitador que simplifica a tarefa do trabalhador, conferindo-Ihe uma autoridade legal em sua interação com o usuário, que se torna, por sua vez, um quase-objeto, isto é, um caso a ser tratado. Enfim, no terceiro tipo, a interação de transformação, o objetivo é "modificar o estado biofísico e psicológico, e até agir sobre os atributos sociais de um cliente ou de um usuário, a fim de melhorar seu bem-estar e seu funcionamento social" (Cherradi 1990, p. 13). Nesse caso, o usuário não é reduzido ao estado de objeto, como nos dois primeiros tipos, mas conserva seu dinamismo próprio, seu poder de iniciativa e mesmo sua capacidade de resistência. A educação está relacionada, mais particularmente, com essa categoria e, nesse sentido, o ensino pode ser qualificado de trabalho interativo de transformação dos alunos. Como em todo jogo, uma dinâmica complexa, uma troca de olhares, de gestos, de palavras se instaura entre os protagonistas, professor e alunos, nesse teatro que é a sala de aula.

Os desafios - Para o professor, em virtude do mandato que the é conferido pela sociedade, o que está em jogo é interagir de maneira tal que possa "modelar" os alunos que estão sob a sua responsabilidade. É assim que ele poderá ganhar o páreo da educação e da aprendizagem. Em contrapartida, para os alunos, o desafio pode ser uma coisa diferente. Como são obrigados a freqüentar a escola até os 16 anos, é possível que, às vezes, eles tenham mais vontade de fazer outra coisa, de fazer de outra maneira ou num outro momento. Muitas vezes eles são mais obrigados a se submeter a seu grupo de colegas do que ao professor. Assim, ganhar, para eles, significa outra coisa. Eles podem dar ao professor - e é o que fazem com freqüência - a ilusão de que ele está com a vitória nas mãos, quando, na realidade, eles procuram salvar as aparências, fazem de conta, trabalham somente pela nota, trapaceiam, tentam passar despercebidos etc. "Para sobreviver na esco- 
la, como em todas as instituições sociais, no sentido de Goffman (1988), é preciso tornar-se dissidente ou dissimulado, salvar as aparências, para ser deixado em paz, sabendo que 'a vida está noutro lugar', nos interstícios, nos momentos em que é possível furtar-se aos olhares, ao controle, à ordem escolar" (Perrenoud 1994, p. 16). Jogador ele também, o aluno apenas reage às ações, às "jogadas" do professor, é um jogador interativo.

Não se sabe quem vai ganhar o páreo, se os professores ou se os alunos, nem tampouco como a partida será jogada, qual será o placar, quem serão os "feridos" e por quanto tempo. Como em todo jogo, reina a incerteza em relação ao desfecho.

Uma relação de forças - Visto que os jogadores possuem interesses diferentes, cuja satisfação pode ser obtida à custa do adversário, uma relação de forças se estabelece entre eles. Seria um erro atribuir ao professor o papel de chefe do jogo e aos alunos o de jogadores passivos. Se no passado isso ocorria, numa organização social hierárquica baseada na autoridade absoluta do mestre, hoje em dia não é mais assim. Se outrora o professor foi totalmente senhor do jogo, a pedagogia nova introduziu uma nova relação de forças na sala de aula. O professor não é mais uma figura autoritária, distante, séria, detentor de um saber incontestável; doravante, ele precisa se aproximar de seus alunos, ouvir e responder às necessidades deles, tornar-se um amigo. O modelo de aluno que recebia passivamente as lições do mestre foi substituído por aquele que, ao ser convidado a expressar suas necessidades e seus interesses, toma a iniciativa de assumir suas próprias aprendizagens.

Essas mudanças fundamentais modificaram consideravelmente a relação de forças entre o professor e os alunos, geraram um funcionamento muito mais imprevisível, dinâmico e menos linear. Nesse aspecto, a relação pedagógica se aproxima muito mais, agora, do tipo de relação social analisado por Goffman (1988). Este, de maneira bastante pertinente, demonstra que toda interação face a face é um "jogo constante de dissimulação (de si mesmo) e de investigação (do outro)" (Winkin apud Goffman 1988, p. 67). Na verdade, quanto mais indefinido é o quadro da interação social, menos clareza há na definição dos papéis e mais os atores precisam se dedicar a um exercício complexo de negociação em que entra uma parcela importante de artimanha, tanto na apresentação de sua própria pessoa quanto na capacidade de adivinhar o outro. Por exemplo, pode-se imaginar a seguinte situação: 
Paulo envia uma mensagem verbal a João e presume que este verá ali apenas uma informação "transparente" e espontânea. Por sua vez, João decodifica essa mensagem como sendo constituída não somente de elementos transparentes, mas também de informações "codificadas". Ao fazer isso, ele presume que Paulo ignora que ele esteja fazendo semeIhante decodificação. Mas Paulo decodifica a decodificação de João e descobre a hipótese que este último fez a seu respeito sem revelar: Paulo está se comportando, aqui, como um verdadeiro jogador de pôquer; ele está "blefando", ele não mostra que sabe tanto. Enfim, João compreende que Paulo compreendeu seu subterfúgio, mas age como se não tivesse percebido nada (Winkin apud Goffman 1988, p. 67). É assim que se elabora, na sala de aula, entre professor e alunos, um verdadeiro jogo de "dribles e contradribles", de estratégias recíprocas e de artifícios. Nessa partida de inumeráveis jogadas, seria um erro acreditar que a sedução é só o apanágio do professor; os alunos não são nada inocentes e também se entregam a manobras semelhantes (Lafon 1992, p. 283).

Uma dinâmica complexa - Essa nova relação de forças tornou complexo o jogo que ocorre na sala de aula. De uma maneira mais específica ao contexto pedagógico, Doyle (1986, p. 34) ilustra bem o emaranhado dessas interações, identificando seis traços fundamentais, específicos à situação de ensino na sala de aula: a) a pluridimensionalidade; b) a simultaneidade; c) a imediatez; d) a imprevisibilidade; e) a visibilidade; f) a historicidade. A pluridimensionalidade se refere à quantidade de eventos e de tarefas diversas que são realizadas nas salas de aula; basta mencionar os componentes relativos aos aspectos físicos, afetivos, intelectuais, sociais, morais de cada um dos alunos. A simultaneidade remete ao fato de que várias dessas dimensões são ativadas ao mesmo tempo. A imediatez lembra a rapidez do ritmo em que esses eventos ocorrem; muitas vezes, o professor é obrigado a tomar decisões em situação de urgência (Van der Maren 1990). A imprevisibilidade está ligada ao aspecto inesperado desses acontecimentos; nem o professor nem os alunos sabem como certas situações vão acabar e em benefício de quem. A visibilidade sublinha a dimensão pública de todas as jogadas do professor e dos alunos; na sala de aula, tanto o professor quanto os alunos se comprometem o tempo inteiro. O professor avalia o comportamento de seus alunos assim como estes suportam os limites do professor. A historicidade manifesta o impacto desses gestos sobre os acontecimentos que estão por ocorrer na sala de aula. Numa partida, todas as jogadas contam 
e são gravadas na memória dos jogadores, servindo de referência conforme a necessidade. É nesse espaço da sala de aula que professor e alunos se encontram e fazem as suas jogadas a fim de ganhar a partida.

\section{No jogo do ensino é preciso recorrer a artifícios, ou seja, seduzir}

Como vimos, há artifícios em toda forma de interação social. Entretanto, no caso específico do trabalho interativo, que visa à transformação do outro, esses artifícios assumem uma forma particular: a persuasão. De fato, como objeto do trabalho interativo, o cliente não pode ser tratado como uma matéria inerte. Ele "possui habilidades e capacidades para barrar, sabotar, retardar e deslocar o efeito da tecnologia interativa, que tem por objetivo transformá-lo ou transformar alguns de seus atributos" (Cherradi 1990, p. 58). As potencialidades reflexivas do cliente, sua autodeterminação e mesmo sua resistência e suas artimanhas dão ao trabalho interativo uma dimensão dinâmica de incerteza.

Quanto maior a mudança no cliente ou no usuário visada pela interação, maiores são a complexidade e a indeterminação que caracterizam a fragilidade de um conhecimento, sob a forma de causa e efeito, dos atributos variáveis e instáveis a serem modificados no usuário. Maior também é a capacidade que tem o usuário de driblar o efeito da tecnologia interativa, utilizada pelo trabalhador interativo; maior, então, é a necessidade, do ponto de vista do trabalhador interativo, de trabaIhar um usuário cujos atributos são apropriados ao tipo de tecnologia interativa utilizada (Cherradi 1990, p. 14).

Nesse tipo de interação, o fato de o usuário ser pró-ativo, isto é, potencialmente capaz de neutralizar ou de barrar os efeitos da intervenção do trabalhador interativo, constitui um sério problema. Quanto maiores forem as necessidades de controle, menos o trabalhador interativo "poderá se desvencilhar e se liberar da vontade do usuário, principalmente quando a tecnologia visa a mudanças importantes no comportamento do cliente" (Cherradi 1990, p. 15). É precisamente por isso que a persuasão surge como a estratégia, o artifício mais útil para o trabaIhador interativo. Persuadir é seduzir.

Persuadir é exercer uma influência não somente cognitiva, mas também afetiva. Persuadir é influenciar por meio da palavra e do gesto, é seduzir a mente e o coração ao mesmo tempo. Nesse sentido, o 
trabalho docente é um verdadeiro trabalho emocional (emotional labor). Aliás, esse tipo de trabalho foi analisado num livro surpreendente, mas muito interessante, sobre as aeromoças. A autora diz isto, a respeito dessa categoria de trabalho:

O trabalho realizado pelo empregado da fábrica de papel de parede exigia a coordenação entre a mente e os braços, entre a mente e os dedos e também entre a mente e os ombros. Consideramo-lo simplesmente como um trabalho físico. A aeromoça executa um trabalho físico quando empurra pesados carrinhos de comida pelo corredor do avião, e um trabalho mental quando prepara e organiza aterrissagens e evacuações de emergência. Porém, enquanto está executando esse trabalho físico e mental, ela também está fazendo algo mais, algo que defino como "trabalho emocional". Esse trabalho exige que a pessoa provoque ou suprima as emoções e que demonstre um controle exterior capaz de produzir um estado de espírito particular nos outros - no caso, o sentimento de que se está cuidando deles num lugar agradável e seguro. Esse tipo de trabaIho exige uma coordenação entre a mente e as emoções, e se apóia em recursos pessoais que associamos à nossa individualidade profunda e integral. (Hochschild 1983, p. 7)

Demoremo-nos alguns momentos nesse exemplo. Em seu trabaIho, a aeromoça recorre à sedução. Uma bela aparência, muita cortesia, solicitude para com o cliente são estratégias de sedução que ela emprega. Essas estratégias são não somente recomendadas, mas exigidas pelo empregador. Entretanto, embora a sedução se expresse através de certas manifestações, outros comportamentos são proscritos: flertar com o cliente, usar uma linguagem de conotação erótica etc. Nesse caso, também, é o empregador quem determina as regras. Assim, em virtude da própria natureza, das exigências e das finalidades do trabaIho, a sedução não pode assumir uma forma qualquer. Há uma delimitação no trabalho de uma aeromoça tanto no que se refere às tarefas que ela tem de realizar como em suas relações com a clientela. Nesse caso, a sedução representa uma estratégia profissional que comporta limites que não devem ser ultrapassados, se bem que não seja em virtude de imperativos morais (afinal de contas, na maioria dos casos, a aeromoça e o cliente são dois adultos que sabem o que querem), mas em virtude da própria eficácia do trabalho a ser realizado. O serviço 
prestado pela aeromoça exige que ela trate todos os clientes da mesma maneira, a fim de que eles apreciem a viagem e escolham novamente a mesma companhia aérea para os seus próximos vôos. Privilegiar um cliente ou demorar-se mais tempo com ele prejudicaria o cumprimento da função, o que poderia provocar o descontentamento dos usuários abandonados. Mas, como resumir a especificidade dessa situação de sedução? Primeiro, constata-se a ausência de manipulação. Reconhecida como uma necessidade profissional, e solicitada pela clientela, a sedução faz parte das estratégias estudadas, praticadas e esperadas nesse contexto. Aliás, quem gostaria de ser servido por aeromoças mal-educadas e descuidadas? Depois, trata-se de uma sedução profissional de duração limitada, ou seja, o tempo de uma viagem de avião. Muito mais do que a moral, é a eficácia do trabalho que determina o que é aceitável ou não.

Pode-se imaginar que a relação pedagógica apresenta características semelhantes às da aeromoça com os seus clientes: "A sedução pedagógica objetiva conduzir, mas por meio de desvios, desvios que passam pela via afetiva na relação professor-alunos" (Lafon 1992, p. 136). O professor também presta atenção nas suas atitudes, nas suas palavras e nos seus gestos em relação aos alunos. Ele sabe que tudo o que diz e faz é interpretado e facilita, ou não, o estabelecimento de uma verdadeira relação pedagógica. O contexto de exercício do trabaIho docente também impõe limites às formas de sedução aceitáveis. Pensemos, sobretudo, nas normas sociais que regem as relações entre adultos e menores. Além disso, a sedução é solicitada pela própria clientela. Imaginemos por alguns instantes um professor cuja atitude arrogante o levasse a tratar os alunos com palavras de desprezo. Não há dúvidas de que esse professor seria incapaz de estabelecer uma relação "sedutora" que Ihe permitisse obter, de outro modo que não fosse pela obrigação, o consentimento dos alunos para realizar as tarefas de aprendizagem. Enfim, a relação entre o professor e seus alunos, assim como a relação entre a aeromoça e os passageiros, se dá num tempo e num espaço limitados. Em contrapartida, o trabalho do professor é muito mais complexo que o da aeromoça. O mandato dele é transformar os alunos que estão sob a sua responsabilidade. Por conseguinte, ele depara necessariamente com resistências e tenta vencê-las. Para isso, ele precisa persuadir, precisa mobilizar um conjunto de estratégias. Ele precisa seduzir, precisa fazer a corte ao consentimento do outro. Em suma, a sedução é consubstancial à relação pedagógica e ao trabalho docente. 


\section{Jogos de sedução}

Mesmo que a sedução seja constitutiva de toda relação humana e, portanto, do trabalho docente, ainda assim, de modo geral, ela é percebida de maneira negativa. Na verdade, ela é associada à manipulação, à mentira, ao engano. Conforme Grisoni,

a tradição ocidental comporta, há muito tempo, um preconceito contra a sedução, que é solidamente associada ao pecado. De Górgias, contemporâneo de Sócrates, até Freud é praticamente o mesmo discurso que prevalece. Seduzir supõe sempre um fundo de engano, de mentira e de ilusão. Uma espécie de fatalidade. Quase uma diabolização.

Ele acrescenta que:

mesmo a etimologia de seduzir comporta o preconceito. Em vez de derivar, como se poderia pensar, de sui-ducere - atrair para si -, termo que daria a idéia de "atração", de "domínio", de "fascinação", "seduzir" vem, na verdade, de se-ducere, que significa colocar à parte, separar, dividir, partilhar. Ele integra o primeiro sentido, mas desviando-o, deformando-o. O movimento do desvio está presente aí, como um reflexo do princípio do mal por excelência. (Grisoni apud Lafon 1992, pp. 33-34)

Essa representação negativa certamente não é estranha à moral judeu-cristã, da qual somos herdeiros. De fato, encontram-se na Bíblia pelo menos dois exemplos que ilustram o que foi dito anteriormente. No Antigo Testamento, o diabo, sob a forma da serpente, seduz Eva e a leva a comer do fruto proibido, o que precipitou o gênero humano para fora do Paraíso. A serpente torna-se, assim, o símbolo do sedutor do mundo inteiro. Todos conhecem, também, no Novo Testamento, as tentações de Cristo durante os 40 dias que passou no deserto. $O$ diabo se apresenta, então, em várias ocasiões, como o grande sedutor que procura enganá-lo.

Além dessas imagens redutoras e negativas da sedução, e considerando que ela é constitutiva de toda relação humana, convém refi- 
nar a análise e examinar suas múltiplas facetas e seus diferentes mecanismos. Será que tudo é negativo na sedução? Todos os sedutores são iguais? São todos motivados pelas mesmas razões diabólicas? Todos utilizam as mesmas estratégias? A sedução tem sempre o mesmo efeito, e esse efeito é sempre perverso?

Para responder a tais perguntas, decidimos examinar várias figuras de sedutores que ficaram famosos ao longo da história. Estamos retomando, desse modo, o argumento de Bataille (1957, p. 26), que, referindo-se a Sade, afirmou que o excesso esclarece o sentido do movimento. Nesse sentido, a análise de figuras de grandes sedutores Sócrates, Casanova, Dom Juan, Valmont, Johannes, Xerazade - leva a ver a mecânica da relação que eles estabelecem com o outro, a fim de compreender melhor como a sedução ocorre nas relações humanas. Isso nos dará a possibilidade de esboçar, em seguida, na última parte, uma resposta para a questão fundamental que nos preocupa: é possível pensar a sedução como estratégia profissional na relação pedagógica?

\section{Seis grandes sedutores}

\section{Sócrates}

Sócrates nasceu em Atenas em 469 e morreu em 399 antes de Cristo. Ele é a imagem paradigmática do professor. Conforme Gusdorf, "a função docente, tal como se desenvolveu no Ocidente, encontra em Sócrates seu patriarca e seu herói exemplar" (p. 87). Ele chega a chamálo de "príncipe encantado do conhecimento" (1963, p. 15). Isso diz a que ponto Sócrates foi um grande sedutor.

Para compreender melhor o sentido do trabalho educativo de Sócrates, convém, inicialmente, precisar a natureza da relação mestre-discípulo entre os gregos. Na época de Sócrates, a educação da juventude repousa na relação entre um "amante" e seu jovem protegido, o "amado". Nessa relação, que não exclui as relações sexuais, o amante é visto como o herói à cuja altura o amado procurará elevar-se progressivamente. A relação repousa igualmente no desejo do amante de seduzir o amado a fim de que nasça neste último um sentimento de fervorosa admiração: “(...) a princípio, a educação era muito 
menos um ensinamento, um doutrinamento técnico do que o conjunto dos cuidados oferecidos por um homem mais velho, cheio de terna solicitude, a fim de favorecer o crescimento de um jovem que alimentava o desejo ardente de corresponder a esse amor, mostrandose digno dele" (Marrou 1981, p. 62).

Era fácil encontrar Sócrates, pois ele ensinava em lugares públicos, interrogando os passantes, conversando com os homens importantes ou com os artesãos e até com os escravos. Sócrates nunca pedia recompensas financeiras em troca dessas conversas. Ele ministrava o seu ensino gratuitamente a quem se dignava conversar com ele. Contudo, seu público-alvo, como diríamos hoje, era sobretudo a juventude ateniense, composta pelos efebos da nobreza da cidade.

Assim como os sofistas, Sócrates também era um grande sedutor. "Ele não se limitava a acolher os jovens, ele os atraía, declaravase amante deles e felicitava-se por saber seduzi-los" (Meunier 1965, p. 137). Em contrapartida, diferentemente deles, era por suas almas que Sócrates estava apaixonado. O Banquete, de Platão, explicita o porquê. Nessa obra, o discurso de Diotima enuncia os diferentes graus do amor.

Deve-se amar primeiro um belo corpo; depois, ao compreender que a beleza de um corpo é irmã da beleza que se acha em todos os outros, amar todos os corpos belos; em seguida, ver a beleza da alma como superior à do corpo; ver-se-á, então, a beleza que está nas leis e nos atos dos homens. Dos atos dos homens passa-se às ciências, para contemplar sua beleza e produzir, com uma fecundidade inesgotável, os discursos e os pensamentos mais magníficos da filosofia, até que, enfim, chega-se a ver apenas uma única ciência, a da beleza absoluta, ideal, eterna, da qual participam todas as belas coisas. (Chambry, Notice sur le Banquet, 1964, p. 19)

Mesmo sentindo-se atraído pelo corpo dos jovens efebos, era à alma deles, entretanto, que Sócrates visava em primeiro lugar: "Conhecendo as conseqüências funestas de um amor demasiado carnal, Sócrates exortava seus amigos a absterem-se, na medida do possível, dos prazeres de Afrodite, e a se afastarem de tudo o que pudesse inflamar as paixões, exasperar os sentidos e dar à alma motivo para se afligir" (Meunier 1965, p. 141). 
Mas, como um tal homem podia seduzir tanto? Não era certamente em virtude da aparência física: "Sócrates, como se sabe, era muito feio, calvo, usava barba, tinha um nariz chato, parecia um sátiro ou um sileno (...)" (Brun 1978, p. 31). É preciso buscar, então, outra explicação. A atração que ele exercia sobre os outros estava ligada, em primeiro lugar, à sua natureza profundamente moral. Xenofonte o apresenta como um ser piedoso, justo, sóbrio, a encarnação do homem perfeitamente bom e feliz. Quanto a Platão, ele afirmava que Sócrates era o melhor, o mais justo e o mais sábio dos homens de sua época (Gusdorf 1963, p. 77). Mas não se pode explicar o impacto de uma pessoa sobre as outras somente por sua virtude moral. "Se fosse preciso encontrar a razão da atração que levou toda a juventude ateniense a seguir Sócrates, seria preciso buscá-la, talvez, no poder mágico que as palavras dele possuíam" (o grifo é nosso; Meunier 1965, p. 136). De fato, Sócrates usava um método, a maiêutica, inspirado na arte de sua mãe, que era parteira, e esse método dava ênfase ao diálogo. Sócrates partia de uma resposta aparentemente simples de seu interlocutor a uma de suas perguntas, decompunha essa resposta em seus elementos para levar esse mesmo interlocutor, já persuadido de possuir um saber verdadeiro, a tomar consciência das lacunas de seu raciocínio. "Para educar os jovens e levá-los a optar pela vida melhor, Sócrates estava continuamente com eles, dedicando-se sobretudo a fazê-los falar e a levá-los a achar, por si mesmos, nos recônditos de sua alma, os princípios mais apropriados a lhes servirem de guia e de luz" (Meunier 1965, p. 139). É assim que a palavra serve a Sócrates de instrumento para ver mais longe e além das aparências. "Fala (assim diz ele a um belo rapaz), para que eu possa vê-lo" (id., ibid.). Sócrates representava o papel do contraditor, daquele que eleva sua voz acima da opinião. Era assim que, ganhando o respeito do outro, ele exercia uma influência ao mesmo tempo intelectual e moral, uma sedução, uma autoridade: "Essa autoridade não está ligada ao exercício de uma função, à intervenção de uma hierarquia de um nível qualquer. $O$ mestre se impõe por seus próprios meios e sem outro artifício; ele força, de certo modo, o consentimento do aluno, se necessário, contra a vontade dele" (Gusdorf 1963, p. 78). Usando os nossos próprios termos, diríamos que Sócrates faz a corte ao consentimento do outro (Gauthier 1993).

Grande sedutor, educador da pólis, hábil retor, Sócrates produzia um poderoso efeito sobre suas "vítimas". Como no caso da serpente sedutora, o veneno de sua palavra penetrava na alma de seus discípulos: 
(...) eu sou como alguém que foi picado por uma víbora: ele se recusa, assim o dizem, a falar de seu caso, exceto para aqueles que, como ele, também foram picados, porque só eles podem saber e desculpar as loucuras que ele ousou fazer ou dizer por causa da dor. Então, eu, que me sinto mordido por algo mais doloroso, na parte mais sensível de meu ser (...), fui picado e mordido no coração ou na alma (...) pelos discursos da filosofia, que penetram mais cruelmente do que o dardo da víbora quando eles encontram uma alma jovem e bem-nascida, e que levam a dizer ou fazer todo tipo de extravagância (...). (Platão 1964, pp. 79-80)

Esse discurso de Alcibíades não deixa nenhuma dúvida quanto à influência que Sócrates exercia sobre os discípulos. Subjugados, enfeitiçados e, às vezes, mesmo irritados com a fineza de suas réplicas, eles reconheciam nele seu mestre. Alcibíades diz também:

Somente diante dele experimento um sentimento que ninguém pensaria achar em mim, a vergonha diante de alguém: ele é o único diante de quem enrubesço. Sinto a impossibilidade de contestar que não é preciso fazer o que ele ordena; mas, quando me afasto dele, sinto também que a ambição de gozar das honras populares se apodera de mim; por isso, me escondo dele, como um escravo fugitivo, e, quando o vejo, sinto vergonha das minhas confissões passadas e muitas vezes preferiria que ele não existisse; mas, se fosse assim, tenho certeza de que o meu desgosto seria ainda maior: cheguei ao ponto em que não sei como fazer com esse homem. (Platão 1964, p. 78)

Longe de abusar da influência que exerce sobre seus discípulos e de sujeitá-los, Sócrates os libera:

Sócrates foi censurado muitas vezes por ter tido como amigos pessoas devassas, como Alcibíades, que o perseguia com suas investidas, ou Crítias, que mais tarde se tornaria um dos Trinta Tiranos. Mas é preciso ressaltar, como fez Xenofonte, que, enquanto Alcibíades e Crítias seguiram o ensinamento de Sócrates, este conseguiu refrear as paixões deles, que só se manifestaram realmente a partir do momento em que eles se afastaram do mestre. (Brun 1978, p. 31) 


\section{Casanova}

Ao contrário dos outros grandes sedutores de mulheres, Giacomo Casanova não é um personagem de ficção. Ele realmente existiu. Nasceu em Veneza, no dia 2 de abril de 1725, e era filho de atores pertencentes à pequena burguesia. Morreu em 4 de junho de 1798. Se ele se tornou um personagem famoso, foi graças à sua própria vida, que ele conta nos 16 volumes de suas Memórias. Dizem que ele tinha um físico bastante agradável e uma viva inteligência. Recebeu uma excelente educação: doutor em direito, conhecia o grego, o latim, o francês e o hebreu, além de se virar em espanhol e em inglês. Possuía profundos conhecimentos de teologia, de filosofia e de matemática. Exerceu diversas profissões, que abandonou logo em seguida: padre, militar, músico e até agente secreto! Dançava como ninguém e era excelente na esgrima e na equitação. Viajante incansável, percorreu incessantemente toda a Europa: da Espanha à Rússia, da Inglaterra à Polônia. Em suma, era um homem fora do comum: bonito, inteligente, culto; tinha tudo para agradar e, ainda por cima, era devorado por uma paixão incontrolável: as mulheres.

Casanova quer seduzir todas as mulheres, ele ama todas elas e não escolhe: mulher do povo ou mulher da corte, jovem ou velha, ele pega aquilo que a vida the traz, autêntico "amontoado insensato de beleza e de lixo, de inteligência e de vulgaridade, verdadeira feira do acaso sem freio e sem escolha!" (Zweig 1937, p. 135). Casanova é essencialmente um ser do prazer. "Não é um sedutor, é um gozador" (Marceau 1948 , p. 142). Ele não somente se deleita com o seu próprio prazer, mas o prazer do outro o enche de deleite. "Ele gosta do prazer que proporciona às mulheres" (idem, p. 116).

Casanova não é um sedutor estratégico, ele não planeja, não calcula. "Se tivesse sido apresentado à devota Madame de Tourvel, Casanova teria, sem dúvida, como Valmont, procurado conquistá-la. Mas, entrementes, para matar sua fome, teria ido à cata das empregadas do castelo, de algumas camponesas das redondezas e da velha tia, ainda por cima" (idem, p. 185). Ele vive o momento e é totalmente dominado por suas paixões. "Nunca tive condições de me ultrapassar e nunca terei" (Zweig 1937, p. 125). Contrariamente aos verdadeiros sedutores, que preferem seduzir as mulheres e que encontram nas artimanhas e subterfúgios seu verdadeiro prazer, Casanova "não sente prazer nas etapas, (...) ele não as respeita" (Marceau 1948, p. 134). "Ele não reflete nem trama; é no infortúnio que vêm até ele, para salvá-lo, inspirações 
astuciosas e muitas vezes geniais; ele nunca prepara, com planos ou cálculos (ele não tem muita paciência), nem a menor das ações" (Zweig 1937, p. 125). É inútil procurar nele motivos ocultos e inconfessáveis ou segredos que não devam ser revelados. Ao contrário, Casanova é um ser de superfície, cujo exterior se confunde com o interior e cujo objetivo se esgota no instante presente.

Como Casanova seduz? De uma maneira muito simples: ele se dá sem reservas, se abandona completamente, possuído pelas mulheres. Elas sentem nele a febre animal: "ele não precisa inventar artifícios líricos ou enganadores para seduzir: Casanova só precisa deixar agir sua paixão e ela trabalha para ele" (Zweig 1937, p. 138). As mulheres se deixam possuir por ele porque sentem que ele é possuído por elas. "Nada se pode ir buscar nesse mestre, nada se pode aprender com ele, pois não existem truques próprios de Casanova, não há uma técnica casanovense da conquista e da sedução. Seu segredo está na sinceridade do desejo, na expressão elementar de uma natureza apaixonada" (id., ibid.).

Casanova não estraga as mulheres, ele não é demoníaco, ele permanece na superfície; é o corpo delas que ele quer, e não a alma. Ele cumpre sempre as suas promessas; por isso, as mulheres que conquistou não se sentem lesadas nem feridas: "Graças a seu magnífico depósito de sensualidade, ele dá prazer por prazer, corpo por corpo e nunca contrai dívidas da alma" (id., ibid.). De fato, suas relações com as mulheres são realmente leais, porque são simplesmente de ordem sexual e sensual (id., ibid.).

Ele não provoca nenhuma catástrofe. Ele fez muitas mulheres felizes e não fez nenhuma delas ficar histérica. Todas saem intactas de uma aventura puramente sensual para voltar à vida cotidiana, ou seja, a seus maridos ou a outros amantes. Mas nenhuma delas se suicida nem se abandona ao desespero; seu equilíbrio interior não é perturbado (...). Ele as inflama sem consumi-las; conquista sem destruir, seduz, mas não desmoraliza (...). (idem, p. 140)

Mais do que isso, as amantes de Casanova ignoram o ciúme, não guardam rancor dele por tê-las deixado e o recomendam umas às outras (idem, p. 147). Elas chegam a escolher uma substituta para ele ou a discutir com ele sobre quem vai ser o seu sucessor. 
Assim, na verdade, ele não conquistou essas mulheres para si mesmo, mas para revelar-lhes uma forma de prazer alegremente aceita, e é por isso que logo elas procuram recrutar novas adeptas para esse culto realizado para torná-las felizes: a irmã mais velha leva a caçula para o altar desse adorável sacrifício; a mãe leva a filha a esse terno professor; cada amante incentiva a outra a participar do rito e da dança desse deus tão pródigo. (o grifo é nosso; id., ibid.)

Não é difícil compreendê-las: Casanova é um sedutor generoso que "não abandona uma mulher sem the deixar dinheiro, seu carro, um marido" (Marceau 1948, p. 190), sem recompensá-la com a certeza de ter sentido prazer no mais profundo da sua própria carne. Em suma, mesmo que as abandone ou que elas decidam abandoná-lo, "...nenhuma delas gostaria que ele fosse diferente do que foi: por isso, Casanova só precisa ser o que é, ou seja, sincero na infidelidade de sua paixão (...)" (Zweig 1937, p. 138).

Dom Juan

Existem duas versões muito conhecidas de Dom Juan: o Dom Juan de Molière, peça de teatro encenada em 1665, e o famoso Dom Giovanni de Mozart, cujo libreto foi composto por Lorenzo da Ponte para a famosa ópera apresentada pela primeira vez em 1787. Considerando a grande semelhança entre o personagem de Dom Juan de Da Ponte e Casanova, cujas características acabamos de apresentar, julgamos que deveríamos analisar apenas o Dom Juan de Molière, que apresenta particularidades diferentes.

A peça de cinco atos apresenta, inicialmente, a cena da deserção de Dom Juan. Ele acaba de abandonar a mulher, Dona Elvira, que reclama vingança por tal afronta. Dom Juan, perseguido pelos irmãos de Dona Elvira, chega a uma pequena aldeia, depois de ter naufragado. No caminho, ele aproveita para seduzir duas jovens camponesas, embevecidas com suas belas palavras e encantadas com seus ares de grande senhor. Em seguida, estando num cemitério diante do túmulo de um Comendador que outrora havia assassinado, ele convida a estátua do morto a vir fazerIhe uma visita, e ela aceita. De volta à casa, à mesa, Dom Juan vê reaparecer a estátua do Comendador, que também Ihe faz um convite. Por bravata, ele aceita o desafio. Finalmente, depois de ter enganado todo mundo, seu pai, Dom Luis, Elvira e os irmãos, além das camponesas Carlota 
e Maturina, em meio a trovoadas e rasgado por um turbilhão de raios, Dom Juan, marido infiel e sedutor impenitente, é precipitado no inferno pelo espectro do Comendador.

Dom Juan quer seduzir todas as mulheres. Sganarelle diz a respeito dele: "Ele gosta de passear de uma relação a outra, e não gosta de ficar parado" (Molière, ato 1, cena 2, p. 38). Entretanto, longe de amá-las apaixonadamente como Casanova, ele procura vencê-las. "Não há nada que possa refrear a impetuosidade dos meus desejos: tenho um coração para amar a terra inteira; e, como Alexandre, desejaria que houvesse outros mundos para poder estender até lá minhas conquistas amorosas" (idem, p. 40). Para ele, as mulheres representam uma espécie de desafio, um objeto de conquista e, como menciona Zweig (1937, p. 144), é impossível pensar em Dom Juan com uma prostituta ou num prostíbulo, porque essas mulheres, de certo modo, já estão ganhas, isto é, vencidas. Ele pratica uma forma de seleção e, quanto mais as mulheres opõem resistência às suas investidas, mais elas se tornam interessantes para ele: "Enfim, não há nada mais doce do que vencer a resistência de uma bela mulher, e tenho, nesse aspecto, a ambição dos conquistadores, que voam perpetuamente de vitória em vitória e não conseguem se decidir a limitar seus desejos" (Molière, ato 1, cena 2, p. 40).

É a beleza, antes de tudo, que atrai Dom Juan. O apelo dessa beleza é, para ele, um imperativo ao qual é obrigado a responder. "De qualquer modo, não posso recusar meu coração a tudo o que vejo de amável; e, assim que um belo rosto o solicita, se eu tivesse dez mil, eu os daria" (idem, pp. 39-40). Entretanto, a mesma beleza que o deslumbra e o faz sucumbir é logo relegada a segundo plano. Dom Juan não se envolve profundamente, não estabelece uma relação íntima com a mulher amada; ele se guarda, se poupa. "Por mais que eu esteja comprometido, o amor que tenho por uma mulher não obriga minha alma a ser injusta para com as outras; tenho olhos para ver os méritos de todas e rendo a cada uma as homenagens e os tributos onde a natureza nos obriga" (id., ibid.). Tudo ocorre, então, como se Dom Juan estivesse vivendo sempre o amor nascente e como se a única coisa que contasse para ele fosse o perpétuo recomeço: "Os amores nascentes, afinal de contas, têm encantos inexplicáveis, e todo o prazer do amor está na mudança" (id., ibid.). Isso explica por que, para esse grande sedutor, a duração é a própria morte. "Queres que nos comprometamos em ficar com o primeiro objeto que nos agarra, 
que renunciemos ao mundo por ele e que não tenhamos olhos para mais ninguém? Coisa bonita, essa, de querer ostentar a falsa honra de ser fiel, enterrar-se para sempre numa paixão e morrer desde a juventude para todas as outras belezas que podem surpreender nossos olhos! Não, não, a constância só é boa para os ridículos" (id., ibid.). Essa recusa da relação que dura levou Felman (1980) a dizer que Dom Juan é o inconstante, o corredor, o viajante, aquele que está sempre de partida, o sem-morada, aquele que está sempre em movimento, que nunca pára.

Compreende-se o porquê de ele não poder nem querer ser fiel: isso significaria se expor à derrota, entregar as armas aos pés do inimigo, que é a mulher. A mulher, como todo adversário, representa o mal, ela é inclusive o instrumento do pecado.

Seus sentidos e seu ser servem apenas para o "mal". Sua natureza, sua própria existência já é sedução e risco; é por isso que a virtude mais perfeita na mulher é só aparência, ilusão e máscara da serpente. Dom Juan não acredita na pureza nem na castidade de nenhuma dessas filhas do diabo; ele sabe que cada uma delas está nua por baixo das roupas, acessível à tentação. (Zweig 1937, p. 144)

É necessário, então, vencer a mulher antes de ser vencido; o tormento de outrem dará até mais emoção à sua busca de prazer. Por isso, contrariamente a Casanova, Dom Juan prefere a sedução às mulheres, fazê-las sucumbir a fazer amor com elas, o prazer maquiavélico ao prazer sensual: "Experimenta-se um prazer extremo em submeter, por meio de cem galanteios, o coração de uma mulher; em ver, dia após dia, os pequenos progressos que se realizaram; em combater, com manifestações de entusiasmo, lágrimas e suspiros, o inocente pudor de uma alma que tem dificuldade em entregar as armas; em derrubar, pouco a pouco, todas as suas pequenas resistências; em vencer os escrúpulos que representam sua honra e em levá-la suavemente aonde gostaríamos que fosse" (Molière, ato 1 , cena 2, p. 40). O donjuanismo é, portanto, muito mais uma paixão do espírito do que uma exaltação do instinto (De Rougemont 1996, p. 104).

Sempre pronto para o combate, Dom Juan elabora diversas estratégias para vencer seus adversários. Gusman, escudeiro de Elvira, preocupado com o destino que Dom Juan reservava para ela, fala-nos disso nos seguintes termos: 
Não sei, na verdade, que homem pode ser esse, se ele realmente agiu conosco com tanta perfídia; e não entendo como, depois de tanto amor e de tanta impaciência demonstrada, de tantos galanteios insistentes, de juramentos, de suspiros e de lágrimas, de tantas cartas apaixonadas, de declarações ardentes e de promessas reiteradas, de tanta emoção e de tanta exaltação que ele deixou transparecer, até vencer, em sua paixão, o obstáculo sagrado de um convento, para colocar Dona Elvira em seu poder, não compreendo, repito, como, depois de tudo isso, ele teria coragem de faltar com sua palavra. (Molière, ato 1 cena 1, pp. 35-36)

Pois é, a técnica final, a arma secreta de sedução de Dom Juan é a promessa de casamento, promessa que é sempre quebrada, evidentemente. Como menciona Sganarelle, o fiel servidor de Dom Juan: "Prometer casamento não the custa nada; é a armadilha de que ele se serve para agarrar as mulheres, e está sempre pronto a pedir todas as mãos em casamento" (idem, p. 36).

Como vimos, o importante para Dom Juan é a conquista. Ao atingir seu objetivo, ele não pode estabelecer uma relação a longo prazo com sua parceira e vai continuar seu combate noutro lugar: "Mas quando nos tornamos senhores, não há mais nada a dizer nem a desejar; toda a beleza da paixão acaba e adormecemos na tranqüilidade de um tal amor" (Molière, ato 1, cena 2, p. 40). Por exemplo, depois de unir-se a Dona Elvira para sempre, pelo casamento, Dom Juan a abandona. Esse abandono, natural na lógica de Dom Juan, será percebido por Dona Elvira como uma traição inqualificável: "Ah, celerado! Agora te conheço por inteiro; e, para infelicidade minha, conheço-te quando não é mais tempo de te conhecer e quando esse conhecimento só pode servir para o meu desespero" (Molière, ato 1, cena 3, p. 48). Enquanto Casanova dá amor, e também se dá, Dom Juan toma, rouba das mulheres o que elas têm de mais precioso: a honra. É o que as deixa tão enfurecidas quando descobrem o logro. De fato, como mostra Zweig:

Assim que são vencidas por sua técnica fria, as mulheres passam a ver em Dom Juan o próprio diabo; elas detestam, com todo $o$ ardor do amor que lhe dedicavam na véspera, o inimigo hereditário e enganador que, no dia seguinte, derrama sobre a paixão que sentiam a ducha gelada de seu riso irônico (...). Elas sentem vergonha de sua própria fraqueza, ficam loucas, furiosas 
e enraivecidas em sua cólera impotente contra o malandro que as enganou, que as fez cair no erro e as espoliou, e passam a odiar todo o sexo masculino. (1937, p. 145)

O que é odioso na sedução de Dom Juan é a violação de sua promessa, que leva ao rompimento da duração, pois toda promessa de casamento é sempre promessa de duração. Por conseguinte, o escândalo, em Dom Juan, é que ele promete sem parar e viola, assim, a "lei" da promessa à qual suas vítimas crêem que ele também está ligado. As vítimas tomam consciência de que Dom Juan não estava realmente em relação com elas, que ele não jogava o mesmo jogo, que havia sempre uma distância entre elas e ele, que "sua boca não estava de acordo com o seu coração" (Molière, ato 5 , cena 2, p. 100). Dom Juan não está em relação com ninguém. Ele transforma a mentira em sistema e não se compromete com a outra pessoa, mas compromete a outra pessoa com ele.

\title{
Valmont
}

No século XVIII, As ligações perigosas, romance de Pierre Choderlos de Laclos, conheceu um sucesso fenomenal. Nele, o autor nos convida, por intermédio de uma troca de correspondências, a acompanhar as estratégias de um sedutor, Valmont, e de sua cúmplice, Madame de Merteuil, bem como o destino infeliz de Madame de Tourvel, vítima desse jogo mefistofélico. Como os grandes sedutores, Valmont possui tudo para seduzir: "...um belo nome, uma grande fortuna, muitas qualidades agradáveis (...)" (C. de Laclos 1996, p. 42). Mas, embora esses atributos sejam essenciais à sedução, eles não bastam para explicá-la. É preciso mais do que isso, alguma coisa mais sutil e mais profunda: uma inteligência astuciosa e o domínio de si mesmo:

\begin{abstract}
A libertinagem é praticada como um esporte - para usar o nosso vocabulário - dos mais difíceis, exigindo uma imensa habilidade, muito sangue frio e todos os dons do homem mundano. Se tivessem sido aplicados noutros objetos, os talentos empregados por Valmont para seduzir as mulheres teriam feito dele um perfeito diplomata ou um poderoso estrategista (...). (Pomeau 1996, p. 47)
\end{abstract}


A melhor maneira de descrever a problemática da sedução em Laclos seria por meio da seguinte citação, na qual Valmont exulta depois de ter vencido, de maneira monstruosa, a resistência de Madame de Tourvel, aquela que ele cobiçava acima de tudo: "Não é como nas minhas outras aventuras, uma simples capitulação mais ou menos vantajosa, e da qual é mais fácil aproveitar do que se orgulhar; é uma vitória completa, obtida numa batalha difícil e decidida por meio de sábias manobras. Não é de surpreender que esse sucesso, que obtive sozinho, seja ainda mais precioso para mim; e o excesso de prazer que senti, com o meu triunfo, e que ainda estou sentindo, não é mais do que a doce impressão do sentimento da glória'” (C. de Laclos 1996, p. 400). Tudo está nessa frase, e mais ainda nas entrelinhas - a personalidade do sedutor: um conquistador pretensioso; o alvo seduzido: a inacessível e insubmissa devota; o motivo: a glória proporcionada pela conquista; a maneira: o cálculo frio; o efeito: o mergulho da vítima no desespero e na morte. Vamos examinar cada um desses diferentes aspectos.

Para Valmont, é importante não somente viver na libertinagem, mas ser reconhecido como o maior dos libertinos. Para ele, seduzir Madame de Tourvel representa o coroamento de sua carreira: "Quando eu tiver obtido esse triunfo, direi a meus rivais: 'Vejam a minha obra e tentem encontrar neste século um segundo exemplo!'” (C. de Laclos 1996, p. 375). Ele se deleita com o efeito que a sua façanha produzirá nos salões da época: "Se eles não podem me ver trabalhando, mostrar-Ihes-ei a minha obra já concluída; eles só terão que admirar e aplaudir" (idem, p. 321). Esse orgulho sem medidas leva-o até mesmo a sacrificar o amor que ele parece sentir por Madame de Tourvel. Sua cúmplice, Madame de Merteuil, leva-o a tomar consciência da impiedosa vaidade que se apossa dele: "Sim, Visconde, você amava muito Madame de Tourvel, e, aliás, você ainda a ama; ama como um louco. Mas, como eu me divertia fazendo-o sentir vergonha, você a sacrificou corajosamente. Você teria sacrificado mil, para não sofrer uma gozação" (idem, p. 451).

Já famoso por suas inumeráveis conquistas, Valmont não pode se satisfazer com presas fáceis, com "(...) a insípida vantagem de ter tido uma mulher a mais" (idem, p. 126). Só Ihe interessa agora a presa mais sublime, mais "desumana": "Você conhece a mulher do presidente, Madame Tourvel, com toda a sua devoção, seu amor conjugal, seus princípios austeros. É ela que vou atacar; é esse o inimigo digno de mim, o objetivo que pretendo alcançar..." (idem, pp. 85-86). Enquanto Dom Juan era indiferente às mulheres, Valmont busca a mulher diferente. E ele pen- 
sa ter descoberto essa diferença em Madame de Tourvel, uma mulher fora do comum. É precisamente essa particularidade que o atrai e inflama.

Além disso, Valmont, como Dom Juan, possui uma lógica guerreira: "conquistar é nosso destino", escreve ele à Marquesa de Merteuil (idem, p. 85). Assim, ele vai em busca da vitória total:

\begin{abstract}
Eu terei essa mulher; roubá-la-ei ao marido que a profana: arrancá-laei até das mãos desse deus que ela adora. Que delícia ser o objeto e depois o vencedor de seus remorsos! Longe de mim a idéia de destruir os preconceitos que a cercam! Eles darão mais valor à minha felicidade e à minha glória. Que ela acredite na virtude, mas que a sacrifique por mim; que seus pecados a apavorem sem poder retê-la e que, invadida pelo terror, ela só possa esquecê-los e vencê-los nos meus braços. Então consentirei que ela me diga: "Eu te adoro". Só ela, entre todas as mulheres, será digna de pronunciar essas palavras. Serei realmente o seu Deus preferido. (C. de Laclos 1996, p. 91)
\end{abstract}

Embora triunfar sobre o outro seja o objetivo final, a maneira de fazê-lo também é importante. Valmont, tal como um gato diante do ratinho, deleita-se com o espetáculo de sua vítima tentando escapar desesperadamente ao seu inelutável destino: "Ah! Que ela se entregue, mas que combata; que ela tenha a força de resistir, mesmo sem ter a força de vencer; que ela saboreie à vontade o sentimento de sua fraqueza e seja obrigada a confessar sua derrota" (idem, p. 126).

A armadilha que esse ilustre sedutor arma para a sua vítima está baseada, em grande parte, numa arma: a carta.

O romance demonstra, de várias maneiras, a eficácia dos escritos epistolares e, a partir daí, o "perigo" desse tipo de "ligação" que é a correspondência (...). Foi por meio das doze cartas que ele a fez ler, às vezes por astúcia e quase constrangido, que ele triunfou sobre a virtude dela. Apenas seu charme não teria sido suficiente para influenciá-la. A impressão física é fugidia e se dissipa. Mas as cartas ficam. (Pomeau 1996, pp. 45-46)

Mais do que isso, a carta é eficaz por ser a expressão constante da ambigüidade: verdade e mentira ao mesmo tempo. "É verdade que 'uma carta 
de amor é sempre uma mentira'. Mas é raro que seja apenas mentira. Para ser crível, o fingimento deve estar apoiado na verdade, deve retomar os elementos dela para adaptá-los a seus fins. Se as declarações de Valmont, orais e escritas, alcançam semelhante sucesso, é porque uma sinceridade, mais ou menos voluntária, se mistura com a mentira" (Pomeau, 1996, p. 50). Nesse sentido, Valmont usa um procedimento comum à sua época. Por exemplo, mesmo alguém como o cavaleiro de Danceny - personagem secundário do romance -, que não é conhecido por mentir e cuja honestidade, em relação ao sentimento amoroso, não pode ser posta em dúvida, utiliza esse jogo da retórica amorosa em sua carta à Marquesa de Merteuil: "De acordo com a folhinha, minha adorável amiga, faz dois dias que você está ausente; mas, segundo o meu coração, já faz dois séculos. Ora, aprendi com você mesma que se deve acreditar sempre em seu coração..." (C. de Laclos 1996, p. 382).

Acontecerá com Madame de Tourvel o que ocorrera com as outras vítimas de Valmont. De fato, ouvindo as confidências de Madame de Tourvel, Madame de Volanges alerta-a várias vezes contra Valmont. Ela diz, inicialmente, que: "(...) entre todas as mulheres que ele cobriu de cuidados, com ou sem sucesso, não há nenhuma que não tenha se queixado" (idem, pp. 96-97); em seguida, ela acrescenta que ele "passou a vida inteira a levar para dentro das famílias a discórdia, a desonra e o escândalo" (idem, p. 141); finalmente, ela diz que seria preciso ouvir "(...) os gritos de cem vítimas imoladas por ele" (id., ibid.). Madame de Tourvel não somente irá fazer parte desse grupo de mulheres abusadas, mas seu destino será ainda pior: essa infeliz aventura a levará à morte. "Valmont destruiu tudo o que servia de base à existência de Madame de Tourvel, desestruturando sua personalidade até levá-la à loucura e à morte" (Pomeau 1996, p. 63).

Johannes

O Diário de um sedutor foi escrito em 1843 por Kierkegaard, filósofo dinamarquês. Dizem que ele teria redigido essa obra para despertar em Régine Olsen, com quem tinha acabado o noivado, uma certa aversão por ele. O livro é apresentado sob a forma de um diário íntimo e de cartas, e conta a ação diabólica empreendida por Johannes, o sedutor, para conquistar Cordélia, a mulher seduzida.

O romance começa com uma breve introdução redigida por um amigo de Johannes que havia encontrado seu diário pessoal. Esse amigo nos apresenta Johannes como um gozador que faz da sedução um projeto "es- 
tético", antes de tudo. Para ele, trata-se de identificar a essência da beleza numa mulher, de se apossar dela e de enaltecê-la até o sublime. "O diário mostra assim que, às vezes, era uma coisa completamente arbitrária que ele desejava, um 'olá', por exemplo, e ele não queria de forma alguma receber mais do que isso, porque tal saudação era o que a pessoa em questão possuía de mais belo" (Kierkegaard 1997, p. 15). O sedutor torna-se, assim, uma espécie de artista que faz surgir o Belo. "Um artista pinta sua bem-amada, e acha prazer nisso, um escultor a forma, e é o que também eu faço, mas no sentido espiritual" (idem, p. 157). Ele diz também: "O essencial é ficar à espreita do que cada uma pode dar e, conseqüentemente, do que ela pede" (idem, p. 84). A pessoa seduzida torna-se, de certo modo, sua obra, e fica Ihe devendo sua beleza revelada. Por conseguinte, o gozo, como projeto estético, se opõe, em Johannes, à sedução vulgar voltada unicamente para a realização do prazer carnal: "Eu não faço questão de possuí-la, no sentido grosseiro do termo, o que me importa é desfrutar dela no sentido artístico" (idem, p. 129). O projeto de Johannes consiste, então, em tornar-se tudo para ela, em fazer com que ela o ame incondicionalmente:

\begin{abstract}
Eu sou um esteta, um erótico, que compreendeu a natureza do amor, sua essência, que acredita no amor e o conhece a fundo, e que se reserva somente a opinião pessoal de que uma aventura galante dura apenas seis meses, no máximo, e de que tudo acaba no momento em que a gente desfruta das últimas provas de amor. Sei de tudo isso, mas sei, também, que o supremo gozo imaginável é o de ser amado, de ser amado acima de tudo. (Kierkegaard 1997, p. 122)
\end{abstract}

A exigência estética desse sedutor o distingue de Casanova, de Dom Juan e de Valmont, ao mesmo tempo. Ao passo que Casanova se comporta como um verdadeiro glutão do amor, pois, para ele, todas as mulheres servem, sem nenhuma distinção, que Valmont seleciona com base na dificuldade do desafio e que Dom Juan encontra prazer na mudança perpétua, Johannes realiza um outro tipo de seleção, que o leva a estetizar a diferença em cada mulher.

Podemos estar apaixonados por muitas, ao mesmo tempo, porque as amamos de diferentes maneiras. Amar uma só é muito pouco; amar todas elas é uma falta de caráter superficial; mas, conhecer-se a si mesmo e amar um número tão grande quanto possível, prender em 
sua alma todas as potências do amor, de maneira que cada uma delas receba $o$ alimento apropriado, enquanto a consciência engloba $o$ todo, é esse o verdadeiro gozo, é isso que é viver. (idem, p. 111)

Esteta da sedução, Johannes não objetiva entrar realmente em relação com a outra pessoa. "De início, ele tirava prazer pessoal da estética; em seguida, ele tirava prazer esteticamente de sua personalidade. Ele tirava prazer, então, egoistamente, de si mesmo (...)" (idem, p. 13). Esse personagem parece, assim, incapaz de manter uma verdadeira relação amorosa partilhada. Para ele, o amor se reduz não somente a receber do outro, mas a ser tudo para o outro: "Aprendendo a amar, ela aprenderá a amar a mim; à medida que ela desenvolver essa regra, o paradigma surgirá, e esse paradigma sou eu" (idem, p. 137). Seu objetivo, então, é tirar prazer da relação para si mesmo, tornando-se mestre do espírito e do coração de sua vítima. A fim de concretizar seus objetivos, o sedutor não poupará nenhum estratagema, nenhuma maquinação. Conseqüentemente, Johannes aparece como um ser frio, calculista, cínico: "Não gosto de sentir vertigem", diz ele (idem, p. 120). Ele só pode conceber uma relação no engano:

Todas as moças que quiserem confiar-se a mim podem estar certas de receber um tratamento perfeitamente estético; somente no fim, é claro, elas serão enganadas; mas também, é uma cláusula da minha estética, pois ou a moça engana o rapaz ou o rapaz engana a moça. (idem, p. 142)

Para seduzir Cordélia, Johannes prepara uma implacável maquinação. Ele a encontra, por acaso, num lugar público. Ao vê-la, ele sente a necessidade de conhecê-la melhor: "(...) preciso conhecê-la em todos os aspectos de sua vida espiritual, antes de começar meu ataque" (idem, p. 76). Para tanto, ele Ihe prepara armadilhas sob a forma de encontros supostamente fortuitos, mas que são, na verdade, inteiramente organizados. "Posso distribuir, como simples bagatelas, encontros que muitas vezes me custaram horas de espera..." (idem, pp. 75-76). Johannes é metódico e acaba descobrindo onde ela mora, quais são seus hábitos, suas companhias, suas idas e vindas. Em seguida, ele se torna amigo de Eduardo, namorado de Cordélia, e usa essa amizade para chegar até ela. Ele chega mesmo a ganhar a estima da tia com quem Cordélia mora, tendo longas conversas com ela. Progressivamente, ele acaba por atiçar a curiosidade 
de Cordélia, levando-a a tornar-se noiva dele. Ele vai mais longe ainda, até o ponto em que, paradoxalmente, após ter despertado o desejo dela com cartas ardentes de paixão, ele se torna pouco a pouco mais distante, provocando nela um fogoso movimento de aproximação. "Ela vai querer me atrair usando os mesmos recursos que usei com ela, ou seja, o erotismo" (idem, p. 211). Ele leva Cordélia a conceber o amor deles como um estado superior às convenções sociais como o noivado e o casamento. Ela decide, então, acabar com o noivado em nome da lógica daquele amor e dar-se logo totalmente a ele. Ele prepara Cordélia para a última noite... que ele é o único a saber ser a última! Tão logo a "possui", ele a abandona.

Tudo está acabado e não desejo vê-la nunca mais. Uma moça torna-se fraca quando ela dá tudo - ela perde tudo; pois a inocência no homem é um elemento negativo, mas na mulher é a essência de sua natureza. Agora, toda resistência é impossível, e só é belo amar enquanto ela dura; quando ela acaba, tudo é fraqueza e hábito. (Kierkegaard 1997, p. 251)

A execução desse projeto leva vários meses. Tudo ocorre de tal maneira que, em nenhum momento, ele estabelece uma verdadeira relação com os outros personagens da história. Cada um dos atores - Eduardo, a tia, Cordélia - não é mais que um objeto útil a seu projeto, um peão no tabuleiro de seu jogo perverso: "Os indivíduos foram apenas estimulantes para ele; ele os jogava para longe de si como as árvores deixam cair suas folhas - ele rejuvenescia, as folhas murchavam" (idem, p. 17).

A sedução estética de Johannes é um processo de crueldade: "Trabalho para desenvolver o contraste, armo o arco do amor a fim de produzir um ferimento mais profundo" (idem, p. 90). Nessa história, tanto a alma quanto o corpo são violados. Johannes deixa Cordélia num estado lamentável, em que ela acredita ser a causa de sua própria infelicidade. Ela se sente culpada e fica com a dolorosa impressão de ser responsável pela ruptura deles.

\section{Xerazade}

Ao descobrir que sua esposa o traía, o sultão Xariyar mandou cortar-Ihe a cabeça. Em seguida, ele ordenou ao vizir que lhe trouxesse to- 
das as noites uma moça virgem. Ele se casava com ela, a deflorava e, ao nascer do dia, mandava matá-la. Desse modo, ele estava certo de nunca mais ser traído pela esposa, impedindo que se repetisse o que ocorrera com ele e com o irmão. Três anos após a implantação desse cruel regime, durante o qual os habitantes do reino acabaram por desertar com suas próprias filhas, o vizir percebeu que não havia na cidade mais nenhuma jovem que pudesse ser esposa do sultão. Como não podia mais obedecer às ordens de seu soberano, ele passou a temer por sua própria vida. Querendo ajudar o pai que Ihe havia revelado o seu temor, Xerazade, a filha mais velha do vizir, insistiu para tornar-se a nova esposa do sultão.

Dizem que Xerazade era uma moça cheia de beleza, de encantos, de vida, de perfeição e que era saborosa (Tomo I, 1993, p. 11). Além do mais, tudo indica que era culta, que ela "havia lido muitos livros, os anais e as lendas dos reis antigos, e a história dos povos passados. Dizem também que possuía mil livros de histórias relativas aos povos das eras passadas, aos reis da Antigüidade e aos poetas. E era muito eloqüente e agradável de ouvir" (idem, p. 11). Em suma, ela tinha tudo para seduzir o sultão - beleza, eloqüência, cultura, fineza -, e assim o fez.

Xerazade, à primeira vista em posição de fraqueza, mostrou-se na verdade capaz de controlar a vontade do sultão todo-poderoso. Ela imaginou um estratagema para inverter a relação de forças e conseguir enganálo. Ela pediu à sua irmã mais nova, Doniazade, que viesse a seu quarto quando o amor com o sultão tivesse sido consumado. A menina devia então, com a permissão do sultão, pedir que ela contasse uma história. "Quando eu estiver com o sultão, mandarei alguém te chamar, e quando tiveres voltado e vires o sultão terminar de fazer aquela coisa comigo, tu me dirás: 'Ó minha irmã, conta-me contos maravilhosos para ajudar-nos a passar a noite!'” (idem, p. 13). Tudo aconteceu como previsto e, no momento certo, Xerazade começou a narrar o conto para a sua irmãzinha. Assim que os primeiros raios de sol despontaram no horizonte, Xerazade se calou. Doniazade exclamou então: "Ó minha irmã, como tuas palavras são doces e gentis e saborosas e agradáveis ao paladar!" (idem, p. 16). Xerazade respondeu: "Mas elas não são nada comparadas ao que lhes contarei esta noite, se eu ainda estiver viva e se o sultão ainda me quiser!" (id., ibid.). O sultão, tão curioso quanto Doniazade para saber a continuação da história, concordou com o pedido dizendo a si mesmo que, de qualquer modo, mataria Xerazade no dia seguinte, quando tivesse ouvido o fim da história.

E o estratagema continuou assim, noite após noite, durante mil e uma noites. E, todas as vezes, ao nascer do dia, Xerazade afirmava que 
o que eles tinham ouvido não era nada comparado ao que ela thes reservava para o dia seguinte. E, todas as vezes, o sultão dizia a si mesmo que não a mataria antes de ter ouvido a continuação da história. Entretanto, sub-repticiamente, enquanto os dias passavam, o tempo foi fazendo o seu trabalho e a sedução agiu positivamente sobre a "vítima". Assim, após essas mil e uma noites passadas em companhia de Xerazade, o rei declarou que sentia a sua "alma profundamente mudada e alegre e cheia da felicidade de viver" (Tomo 2, 1993, p. 1013) e que havia abandonado todo desejo de vingança. Por outro lado, a sedução parece ter tido também um efeito positivo sobre a própria Xerazade. Seu hábil artifício, que no início Ihe havia permitido evitar o seu destino funesto, parece ter se metamorfoseado, em seguida, numa verdadeira relação amorosa. Ela não somente salvou sua vida, mas, de acordo com a narrativa, Xerazade e o sultão Xariyar, e os três filhos nascidos durante essas memoráveis noites, "viveram na delícia e na felicidade e na alegria, durante anos e anos, passando dias mais admiráveis que os anteriores..." (idem, p. 1.018).

As mil e uma noites representam a exploração da sedução na relação com o tempo (Kattam, 1980). Enquanto todas as outras jovens esposas do sultão Xariyar eram assassinadas ao fim da primeira noite, Xerazade inverte o processo e resolve seduzir o sultão. Ela alimenta o desejo do sultão de saber sempre mais e pode, assim, se integrar numa relação durável com ele. Ao contrário de Dom Juan, para Xerazade a vida está na duração e não na ruptura, na continuidade e não no instante. A sedução do sultão, noite após noite, lhe possibilitará vencer o destino inelutável que a esperava: a morte. A narrativa d'As mil e uma noites vem demonstrar que é possível manter o desejo por um longo período de tempo, a despeito da inevitável rotina para a qual o dia-a-dia nos arrasta. $O$ desejo é mantido vivo porque há uma promessa constantemente reiterada por Xerazade de que o dia seguinte trará aventuras ainda mais extraordinárias.

\section{Lições de sedução}

O que pode ser depreendido dos jogos de sedução desses seis personagens? Três lições emergem da análise comparativa do trabalho desses hábeis sedutores. Em primeiro lugar, percebe-se que os sedutores se diferenciam pelo fato de jogarem com suas vítimas ou de zombarem delas. Em seguida, eles se distinguem na medida em que a relação que estabelecem expira no instante ou se prolonga no tempo. Finalmen- 
te, os jogos de sedução levam seja a excluir, seja a manter a outra pessoa no jogo. Examinemos brevemente esses três pólos contrastantes.

\section{Jogar o jogo ou aproveitar-se do jogo}

Certos sedutores jogam o jogo, enquanto outros se aproveitam do jogo, isto é, jogam uma espécie de jogo duplo no qual o que dizem ao outro não corresponde à sua intenção ou ao seu comportamento real mas não declarado. Na verdade, para esses sedutores, o outro não é um parceiro de jogo, não é um sujeito de relação, mas um simples objeto do qual se aproveitam, de que se servem a seu bel-prazer.

É possível reunir Sócrates, Casanova e Xerazade na categoria daqueles que jogam o jogo, ao passo que Dom Juan, Valmont e Johannes pertencem àqueles que se aproveitam do jogo. De fato, Sócrates entra realmente em relação com seu discípulo, procura o conhecimento com ele, e não à custa dele. Ele não se serve do outro para seus próprios fins narcisistas, mas visa caminhar com ele em direção à sabedoria. Casanova entra numa relação passional com suas parceiras, busca o prazer partiIhado. Ele não lhes promete nada além do que pode Ihes dar, ou seja, o gozo. O jogo de Xerazade parece mais ambíguo. Em primeiro lugar, é preciso reconhecer que Xerazade cumpre suas promessas. Tal como prometido, a cada noite, e durante mil e uma noites, ela contava uma história mais impressionante do que a anterior. Contudo, o mais fundamental ainda é que, durante os mil e um dias em que o sultão tratava dos negócios

do reino, Xerazade permaneceu totalmente fiel a ele. E, paulatinamente, enquanto no início ela parecia zombar do rei, por intermédio de um plano sutil armado com a irmã, ela acabou estabelecendo uma relação profunda e feliz com ele. Esse tipo de sedutor expresso pelas figuras de Sócrates, Casanova e Xerazade tenta seduzir a fim de que o outro entre no jogo; não há jogo duplo aqui, pois cada um dos parceiros joga o mesmo jogo.

Por outro lado, Dom Juan, Valmont e Johannes se aproveitam literalmente de suas vítimas. Cada um à sua maneira faz a outra pessoa acreditar que ele está em relação com ela, mas, na verdade, age de acordo com um outro esquema. Por conseguinte, esse tipo de sedutor joga um "jogo duplo" a fim de ganhar a partida, cujos verdadeiros lances ele é o único a conhecer. Dom Juan finge se comprometer com sua belda- 
de através da promessa de casamento, mas, na realidade, se guarda para todas as outras. Valmont faz Madame de Tourvel acreditar que a sua verdadeira motivação é o amor que sente por ela, quando, na realidade, está jogando um outro jogo em cumplicidade com Madame de Merteuil, no intuito de realizar o coroamento de sua carreira de grande sedutor. Enfim, Johannes simula o amor para desfrutar, de maneira egoísta, de seu domínio sobre Cordélia. Em suma, esses sedutores são, de certa maneira, os únicos a jogar; eles jogam para si mesmos. Eles planejam, de maneira egoísta, tirar proveito da relação. Assim, Dom Juan, Valmont e Johannes não querem gozar com os outros, mas dos outros. Eles não cumprem suas promessas, nunca cumprem com a sua palavra. Gusdorf (1971) nos faz compreender a relação íntima que existe entre a sedução e a linguagem. Para ele, a autenticidade da comunicação não está numa certa representação de um ideal da linguagem pura (verdadeira), mas no esforço constante de manifestação do homem. Não há verdade na palavra em si, mas pode haver uma correspondência entre palavra e ato. Ora, o problema desses sedutores é justamente o fato de que, neles, não há correspondência entre palavra e ato. "A ética da palavra, numa experiência renovada dia após dia, afirma uma exigência de veracidade. Trata-se de dizer a verdade, mas não se pode dizer a verdade sem ser verdadeiro. Assim se define a necessidade de colocar a limpo as relações de si para o outro e de si para si" (1971, p. 121). Além disso: "O homem de palavra não paga com palavras, mas paga com sua pessoa" (id., ibid.).

\section{Seduzir para durar ou por um instante}

A relação com o tempo constitui uma outra diferença importante entre os sedutores. Sócrates, Casanova e Xerazade produzem uma sedução que, de certa maneira, tende a durar, enquanto Dom Juan, Valmont e Johannes empenham suas energias em gozar o último momento da queda da vítima.

Embora Sócrates também esteja interessado nos corpos jovens e viris, seu objetivo é bem mais profundo. Ele persegue um objetivo a longo prazo, o de fecundar as almas. Casanova vive o instante, mas sua ação se insere na duração. Ele busca a continuidade do prazer, a eterna aventura (Zweig 1937, p. 128). Ele vive no imediato, mas, paradoxalmente, suas relações com as mulheres são duráveis: elas permanecem 
apegadas a ele, conservam uma lembrança deleitável de sua pessoa e adorariam reviver uma vez mais uma sensual noite de amor em seus braços. Embora o objetivo primeiro de Xerazade tenha sido o de pôr fim à matança infernal ordenada pelo sultão e de escapar assim à morte, sua relação com Xariyar transformou-se, em seguida, em verdadeiro amor. Ela viveu feliz com ele "durante anos e anos, passando dias mais admiráveis que os anteriores..." (Tomo 2, 1993, p. 1.018). Só aparentemente Dom Juan, Valmont e Johanes se inserem na duração. A realização do objetivo deles exige, às vezes, meses de preparação e de esforços. Entretanto, esse objetivo nunca se volta para a continuidade. Esses sedutores procuram algo que está além da relação. Só uma idéia os anima, a queda da vítima, e, quando esse objetivo se realiza, eles a abandonam sem remorsos. Dom Juan nem bem acaba de se casar com Dona Elvira e já está partindo para iniciar outras conquistas; Madame de Tourvel é abandonada por Valmont assim que é conquistada por ele; depois que o amor se consuma, Johannes abandona Cordélia sem nenhuma explicação.

\section{Excluir ou manter o outro no jogo}

Nos seis exemplos analisados, é possível constatar um forte apego da pessoa seduzida por seu sedutor. Todavia, outra diferença importante surge entre os diversos personagens. Dois grandes tipos de efeito aparecem claramente: a exclusão da pessoa seduzida ou sua conservação no jogo. Sócrates, Casanova e Xerazade fazem a outra pessoa entrar no jogo, transmitem-Ihe o prazer de jogar com eles. São sedutores que mantêm a relação com a pessoa seduzida, a qual nunca é posta fora do jogo. O Banquete, por exemplo, é a encenação dessa relação pedagógica que continua entre Sócrates e seus discípulos. Alcibíades, aluno cheio de artimanhas, continua mesmo assim querendo conservar sua relação com o mestre. Nenhuma das mulheres seduzidas por Casanova é excluída do jogo após uma aventura com ele. Ao contrário, todas permanecem sendo parceiras potenciais para novas partidas. Quanto a Xerazade, ela põe fim ao trágico destino ao qual estavam condenadas as outras mulheres do sultão. Ao contrário delas, ela não é impiedosamente excluída do jogo, mas consegue transformá-lo em seu parceiro para o resto da vida. Por outro lado, o jogo duplo de Dom Juan, de Valmont e de Johannes coloca suas vítimas literalmente fora do jogo, retirando delas, definitivamen- 
te, o prazer de jogar o jogo do amor. Cada uma das três vítimas se sente profundamente ferida. Dona Elvira, ao compreender que perdeu sua honra, passa a odiar não somente Dom Juan, mas todos os homens; Madame de Tourvel entra para o convento e morre de desgosto por causa de Valmont; Cordélia, desesperada, permanecerá para sempre persuadida de que é responsável pela partida de Johannes.

Concluindo, a análise comparativa dos seis personagens mostra que a sedução não é um conceito unívoco: ela se manifesta de diferentes maneiras e emprega métodos diversos. Entretanto, é antes de tudo a partir de seus motivos e de seus efeitos que é possível categorizar o trabalho desses sedutores. Como observamos, Sócrates, Casanova e Xerazade possuem motivos que possibilitarão a continuidade do jogo e o desabrochar da vítima: Sócrates conduz seus discípulos aos caminhos da virtude e da sabedoria, Casanova abre as portas da volúpia para as suas conquistas e Xerazade leva Xariyar para o reino da felicidade. Em oposição, Dom Juan, Valmont e Johannes, cheios de motivos baixos, imolam suas vítimas e as precipitam no mais profundo desespero.

\section{A sedução como estratégia profissional no âmbito do ensino}

Como vimos anteriormente, embora a sedução seja constitutiva das relações humanas, ela é muitas vezes percebida de forma negativa. Entretanto, os seis exemplos de sedutores que analisamos mostram que nem tudo é negativo na sedução. Contrariamente às estratégias de sedução de Dom Juan, Valmont e Johannes, as de Sócrates, Casanova e Xerazade não parecem acarretar efeitos deploráveis.

Também ocorre assim no ensino. A análise de depoimentos de professores, feita por Lafon, confirma a impossibilidade que eles sentem de fazer economia de sedução em seus contatos diários com os alunos: "Nessas conversas, que são apenas 'depoimentos' sobre a sedução e sobre as atitudes de sedução dos professores, só podemos constatar uma coisa: a sedução tem um papel importante, incontornável, na relação pedagógica" (1992, p. 163). Todos os professores que ele entrevistou admitiram recorrer a certas estratégias de sedução em sua prática profissional (Lafon 1992, p. 293). E, nesse aspecto, os meios que utilizam não são realmente muito diferentes dos recursos empregados pelos grandes sedutores da história: 
Como exercer esse poder de sedução na relação pedagógica? Através dos mesmos "desvios" por que passa toda sedução, digamos, clássica. Por meio de "estratégias" que são formas de "manipulação", são "procedimentos" que podem chegar às "cordas" da "encenação", que provêm do "teatro", do "circo", do "ator", da "demagogia", sem esquecer o "corpo", mesmo que ele seja citado aqui de maneira mais discreta, mas nem por isso é esquecido (...). (idem, pp. 167-168)

Entretanto, embora não possam deixar de usá-la, os professores adotam uma posição ambivalente a respeito da sedução. Lafon (1992, p. 139) indica que, das 12 entrevistas que fez com professores, três a consideram francamente positiva, quatro se opõem veementemente e cinco têm um ponto de vista dividido. Isso o leva a dizer que:

Pode-se constatar, por outro lado, que, quando se fala de sedução numa conversa, o positivo e o negativo se conjugam com mais ou menos ambigüidade para cada um, com uma margem importante de "mas", quer eles sejam "a favor" ou "contra" por princípio. Eles dizem "Sou a favor, mas é perigoso", não importa quais sejam os perigos evocados: "Sou contra, mas é difícil não usar". Pouco importa quais sejam as razões indicadas, num caso como no outro, a tomada de posição inicial é reforçada ou suavizada para justificar a traição feita a si mesmo ao desenvolver a sua reflexão. As pessoas ficam presas no jogo entre princípio e prática, entre ética e realidade. E, mais uma vez, quer sejamos a favor, quer sejamos contra, a sedução seduz! (Lafon 1992, p. 163)

Noutras palavras, quer seja julgada "positiva" ou "negativa" pelos professores (idem, p. 282), todos entre eles reconhecem que não podem deixar de recorrer à sedução em sua prática. Esses professores devem ser taxados, como Cifali dá a entender (1994, p. 196), de inconseqüentes ou de aéticos?

É essencial fazer a seguinte pergunta: é possível pensar a sedução como estratégia profissional na relação pedagógica? Em outras palavras, quais são as condições que possibilitam um uso positivo da sedução? Para responder a essa pergunta, convém, em primeiro lugar, situar a problemática da sedução no contexto do jogo pedagógico e reto- 
mar, em seguida, as lições que tiramos da análise dos sedutores, aplicando-as desta feita à relação professor-alunos.

A análise do jogo pedagógico, tal como ocorre entre o professor e os alunos, na sala de aula, põe em evidência vários elementos. Em primeiro lugar, contrariamente à maioria dos sedutores, o professor não dispõe de um tempo infinito para seduzir suas "vítimas". Logo no início do ano letivo, desde o primeiro dia de aula, ele deve estabelecer um contato com alunos que the são mais ou menos estranhos e fazê-los aceitar as regras de funcionamento de sua sala de aula. Ele só pode exercer sua "influência" durante aquele tempo em que os alunos estão sob a sua responsabilidade, período delimitado pelo calendário escolar. Além disso, o jogo da sedução ocorrerá num espaço especializado, associado ao trabalho intelectual que não é - devemos admitir - particularmente propício ao estabelecimento de relações íntimas. Ademais, a relação pedagógica é uma relação obrigada. De fato, nem o professor nem os alunos se escolhem uns aos outros. E o que é pior, ao contrário do professor, os alunos são obrigados a estar na escola. Por outro lado, contrariamente aos seis casos analisados, o professor não tem de seduzir somente uma pessoa a cada vez, mas um coletivo: ele precisa conseguir influenciar não somente cada criança em particular, mas também o grupo como um todo. Enfim, não se pode esquecer a relação assimétrica entre $o$ adulto que é professor e os alunos que estão sob a sua responsabilidade. Ao delegar-Ihe a responsabilidade de instruir e educar as crianças, a sociedade espera que ele exerça uma certa forma de autoridade sobre eles. Logo de saída, essas condições próprias ao contexto do ensino impõem, assim, limites àquilo que poderá se revelar como sendo, ou não, estratégias eficazes de sedução no contexto profissional.

Examinemos, agora, como podemos pensar a sedução em função dos limites da relação pedagógica. O jogo pedagógico é, em parte, determinado pelos limites e regras dentro dos quais se situa o ensino no ambiente escolar. Assim, o professor não pode jogar qualquer jogo. $\mathrm{Na}$ qualidade de trabalhador investido de um mandato particular, ele deve trabalhar no intuito de instruir e educar os jovens. Entretanto, não se pode esquecer que os limites e as regras que orientam seu trabalho dizem respeito, sobretudo, às modalidades gerais da interação. O professor possui, por conseguinte, uma certa margem de manobra no estabelecimento das regras do jogo em sua própria sala de aula. Nesse contexto, o que significa "jogar o jogo"? Resposta: cumprir com a sua promessa. A adequação entre a palavra e 0 ato tem por efeito o estabeleci- 
mento de um clima de confiança, garantia de uma relação de qualidade. Nesse sentido, tal como Sócrates, Casanova e Xerazade, o professor aplica seus artifícios e suas estratégias de sedução não para enganar o outro, mas para compremetê-lo a jogar com ele. Inversamente, não cumprir com sua promessa é fazer como Dom Juan, Valmont e Johannes, ou seja, jogar jogo duplo, o que, no caso do professor, significa zombar dos alunos. Jogar o jogo, em termos de pedagogia, é, então, numa certa medida, responder ao mesmo tempo às exigências da instituição educativa, contribuir para que suas finalidades principais sejam atingidas e estabelecer com os alunos uma relação em que cada um, de acordo com as regras, jogue o mesmo jogo da sedução.

A relação de sedução entre o professor e os alunos não tem nem a importância de um casamento, nem a fugacidade da aventura de uma noite. Considerando que o ano letivo dura dez meses, uma sedução profissional eficaz precisa se inserir nessa duração semiprolongada. Como a sedução pedagógica tem um termo, as estratégias devem ser pensadas em função desse fim, o que quer dizer que elas devem considerar, desde o início da relação, a partida dos alunos. Seduzir na duração impõe um limite à possibilidade de enganar o outro. De fato, a exigência do tempo impede que a mentira perdure. Cedo ou tarde, o professor deverá prestar contas diante do tribunal de seus alunos sobre a veracidade de seu ser, de seus gestos e de suas palavras.

O que pressupõe que o professor, desde os primeiros contatos com a turma, saiba que, quaisquer que sejam as metamorfoses sofridas pelo encontro, ele jamais deverá perder de vista o fato de que ele só pode ser um "objeto transacional" em direção ao saber, que ele está ali de passagem. Ele jamais deverá esquecer que deve realizar um trabalho de luto sobre a sua própria pessoa e não sobre os saberes que detém, que ele deve realmente abandonar seu desejo de onipotência - sua fantasia de onipotência. (Lafon 1992, p. 291)

Assim, nessa perspectiva psicanalítica, a sedução pedagógica difere daquela empregada pelos sedutores, pois ela ensina a superação de si mesmo, o luto em relação a seu próprio narcisismo. De fato, contrariamente a personagens como Dom Juan, Valmont e Johannes, que querem ser indispensáveis, mesmo que seja para ir embora assim que a noite termina, o pedagogo ensina o aluno a não 
precisar dele. Dessa maneira, seduzir de modo durável vai de encontro ao narcisismo dos professores que devem:

\begin{abstract}
assumir o caráter mais paradoxal de seu trabalho: instituir em sua própria ação o princípio de seu desaparecimento. Nesse sentido, sua utilidade social se baseia em sua capacidade de aceitar tornar-se inútil. Eles precisam, efetivamente, saber morrer continuamente para o aluno, para aquele que se formou. A autonomia dos parceiros tem esse preço. (Ardoino 1980, p. 136)
\end{abstract}

Por outro lado, segundo Lafon (1992), toda relação professor-alunos começa por uma sedução primeira, sedução festiva, como diria Cifali (1994). "Ora, o perigo da sedução na relação pedagógica reside na própria natureza da sedução que está associada à imediatez e ao prazer" (Lafon 1992, p. 135). A sedução, limitada ao momento do prazer, não permite a sublimação exigida por um trabalho que se prolonga no tempo: "A sublimação seria o resultado de um trabalho no tempo, de esforços, de deslocamentos, para alcançar o princípio de uma realidade que termina, muitas vezes, de forma dolorosa" (o grifo é nosso; idem, p. 137). Nessa relação a meio termo entre os alunos e o professor, este deve, como Xerazade, cativá-los dia após dia. É assim que eles poderão, progressivamente, desviar seu olhar do professor em direção aos objetos do conhecimento.

A realidade da relação professor-aluno começa além da sedução primeira, o prazer do aluno devendo ser adquirido por ele, que deve apossar-se dele, torná-lo seu, e não querer agradar ao outro. O prazer se torna, então, a vitória por ter ultrapassado o "nãosabido", e não somente o olhar do outro que aprova. (idem, p. 291)

Disso depende a sobrevivência de um e do outro, do professor como profissional centrado sobre a aprendizagem (e não sobre si mesmo), e do aluno como aprendiz, cada um dando sentido, assim, à sua presença na sala de aula.

Dessa maneira, a sedução pedagógica bem-sucedida seria aquela cujo efeito é manter os alunos no jogo, ou seja, que consegue alimentar o compromisso deles com suas próprias aprendizagens. Contrariamente às vítimas de Dom Juan, de Valmont e de Johannes, que partilham 
o triste destino de serem excluídas do jogo, os alunos, tais como os discípulos de Sócrates, as mulheres de Casanova e o sultão Xariyar, não somente adquirem o prazer do jogo, mas se desenvolvem jogando. Manter os alunos no jogo corresponde, sem dúvida, muito mais a um critério pragmático do que moral ou psicanalítico. Agir de outra maneira seria arrastar a relação para um terreno que não é mais o da pedagogia e que não conduzirá à realização dos objetivos de educação e de aprendizagem, que são os objetivos da escola. É esse também o ponto de vista adotado por Mercier (1997) em seu estudo sobre a sedução na relação de ajuda. Ele mostra que a sedução é compatível com a relação de ajuda e que, se devemos proscrever certas formas de sedução, não é, em primeiro lugar, por motivos morais, mas com base numa postura pragmática. Por exemplo, numa relação entre um trabalhador social e um usuário, as relações sexuais deverão ser evitadas porque tornam a relação de ajuda impossível, ou seja, não eficazes, pois eliminam a distância interpessoal necessária a toda relação profissional: "ninguém 'vai para a cama' com alguém com o objetivo de ajudá-lo" (1997, pp. 43-44). Nesse sentido, "as razões para se abster de relações sexuais na relação de ajuda não são razões morais, mas sim razões de eficácia” (p. 44).

\section{Conclusão}

O ensino, como trabalho interativo, precisa que se recorra continuamente a jogos de sedução. Esses jogos podem apresentar conseqüências positivas ou negativas e, por conseguinte, merecem um exame minucioso. A esse respeito, Lafon (1992) sublinha a importância de não deixar a sedução no campo do impensado, num intervalo da consciência. Ele insiste na necessidade, para o professor, de reconhecer os perigos inerentes à sua posição de poder, como o seu narcisismo e sua tendência a manipular os alunos. Podemos acrescentar que, não somente o professor deve estar consciente dos perigos da sedução, mas deve também conhecer e explorar as enormes possibilidades que ela oferece. É nesse sentido que falamos da sedução como instrumento de gestão da relação com o outro no contexto profissional do ensino. Por isso, seria um erro recusar a sedução no campo da pedagogia e reduzi-la à manipulação e à mentira, brandindo a imagem da belle âme em nome de uma suposta pureza das relações. A nosso ver, a análise da sua própria relação com o outro no seu trabalho, tanto no contexto da formação inicial quanto no da formação contínua, dará ao profes- 
sor a possibilidade de gerir melhor suas estratégias de sedução, a fim de transformá-las não em instrumentos de servidão e de destruição do outro, mas sim em instrumentos necessários de liberação.

\title{
Images of seduction at Pedagogy. "Seduction as a professional strategy"
}

\begin{abstract}
This text has as objective answering to a question a long time hidden in education, that is, if is possible to think seduction as a professional strategy in pedagogical relation. To such, we analyzed six figures of literature great seductors: Socrates, Casanova, Don Juan, Valmont, Johannes and Sheherazade. This analysis allowed for understanding that, if seduction is sometimes related to allurement, on the other hand, it is far from being always negative. This way, we recognize some characteristics of a positive seduction, i. e., we identify condictions of an ethical use of seduction at teaching.
\end{abstract}

\section{Bibliografia}

ALBERONI, F. L'érotisme. Traduzido para o francês por R. Coudert. Paris: Pocket, Ramsay, 1987.

ARDOINO, J. Éducation et relation: Introduction à une analyse plurielle des situations éducatives. Paris: Gauthier-Villars, Unesco, 1980.

BATAILLE, G. L'érotisme. Paris: Minuit, 1957.

BAUDRILLARD, J. De la séduction. Paris: Galilée, 1979.

BERTHELOT, A. Le roman courtois. Une introduction. Paris: Nathan, 1998.

BRUN, J. Socrate. Paris: Presses Universitaires de France, 1978.

BRUCKNER, P. e FINKIELKRAUT, A. Le nouveau désordre amoureux. Paris: Seuil, 1977.

CALVINO, I. Le chevalier inexistant. Paris: Seuil, 1962.

CAZENAVE, M.; POIRON, D.; STRUBEL, A.; ZINK, M. L'art d'aimer au Moyen Âge. Paris: Philippe Lebaud, 1997.

CHERRADI, S. Le travail intéractif: Construction d'un objet théorique. Mémoire.

Faculté des études supérieures. Université de Montréal, 1990. 
CHODERLOS de LACLOS, P. Les liaisons dangereuses. Edição estabelecida por René Pomeau. Paris: Garnier-Flammarion, 1996.

CIFALI, M. Le lien éducatif: Contre-jour psychanalytique. Paris: Presses Universitaires de France, 1994.

DANTE. La divine comédie. L'enfer. Traduzido para o francês por J. Rissot. Paris: Garnier-Flammarion, 1992.

DA PONTE, L. Livret de Don Giovanni pour W.A. Mozart. Nova York: CBS, 1979. DE ROUGEMONT, D. L'amour et l'Occident. Paris: Plon, 1972. . Les mythes de l'amour. Paris: Albin Michel, 1996.

DUBY, G. Mâle Moyen Âge. De l'amour et autres essais. Paris: Flammarion, 1988.

ENRIQUEZ, E. De la horde à l'État. Essai de psychanalyse du lien social. Paris: Gallimard, 1983.

FEBVRE, L. Amour sacré, amour profane. Paris: Gallimard, 1944.

FELMAN, S. Le scandale du corps parlant. Don Juan avec Austin ou La séduction en deux langues. Paris: Seuil, 1980.

GAUTHIER, C. "Le pédagogue et ses ruses". In: Tranches de savoir. L'insoutenable légèreté de la pédagogie. Montréal: Logiques, 1993.

GAUTHIER, C.; DESBIENS, J.-F.; MALO, A.; MARTINEAN, S.; SIMARD, D. Pour une théorie de la pédagogie. Recherches contemporaines sur le savoir des enseignants. Sainte-Foy: Presses de l'Université Laval, 1997.

GIROUD, F. e LÉVY, B.-H. Les hommes et les femmes. Paris: Olivier Orban, 1993.

GOFFMAN, E. Les moments et leurs hommes. Paris: Seuil/Minuit, 1988.

GUSDORF, O. Pourquoi des professeurs? Paris: Payot, 1963. . La parole. Paris: Presses Universitaires de France, 1971.

HOCHSCHILD, A.R. The Managed Heart. Commercialization of Human Feeling. Berkeley: University of California Press, 1983.

KATTAM, N. "Du désir dans Les mille et une nuits". In: OLENDER, M. e SOJCHER, J. (orgs.) La séduction. Paris: Aubier Montaigne, 1980.

KIERKEGAARD, S. Le journal d'un séducteur. Traduzido para o francês por O. Prior e M.H. Guignot. Paris: Gallimard, 1997. 
KOFMAN, S. Le respect des femmes. Paris: Galilée, 1982.

KUNDERA, M. La lenteur. Paris: Gallimard, 1995.

LAFON, J. De la séduction dans la transmission des savoirs. Vers une gestion de la séduction dans la relation pédagogique. Tese de doutorado. Bordeaux : Université de Bordeaux, 1992.

LAPLANCHE, J. Nouveaux fondements pour la psychanalyse. Paris: Presses Universitaires de France, 1987.

LAURENT, J. Du mensonge. Paris: Plon, 1995.

MALHERBE, J.-F. La conscience en liberté. Montréal:Fides, 1997.

MARCEAU, F. Casanova ou l'anti-Don Juan. Paris: Gallimard, 1948.

MARROU, H.-I. Histoire de l'éducation dans l'Antiquité. Le monde grec. Paris: Seuil, 1981.

(-). Les mille et une nuits. Traduzido para o francês por C. Mardrus. Tomos 1 et 2. Paris: Laffont, 1993.

MERCIER, A. Séduction et relation d'aide: La négociation de la distance interpersonnelle et du niveau d'intimité. Dissertação de mestrado. Département de counseling et orientation, Université Laval, 1997.

MEUNIER, M. La légende de Socrate. Paris: Albin Michel, 1965.

MILTON, J. Le paradis perdu. Traduzido para o francês por Chateaubriand. Paris: Gallimard, 1995.

MOLIÈRE. Dom Juan ou le festin de Pierre. Paris: Bordas, 1973.

OLENDER, M. e SOJCHER, J. (orgs.) La séduction. Paris: Aubier Montaigne, 1980.

OVÍDIO. L'art d'aimer. Traduzido para o francês por H. Bornecque. Paris: Gallimard, 1974.

PERRENOUD, P. Métier d'élève et sens du travail scolaire. Paris: ESF, 1994.

PLATÃO. Le banquet. Phèdre. Traduzido para o francês por E. Chambry. Paris: Garnier, 1964.

POMEAU, R. "Préface". In: CHODERLOS de LACLOS, P. Les liaisons dangereuses. Paris: Garnier-Flammarion, 1964.

. "Introduction". In: CHODERLOS de LACLOS, P. Les liaisons dangereuses. Paris: Garnier-Flammarion, 1996. 
ROSSELOT, E. L. Tese sobre S. Richardson (Em torno de Lovelace). Cota: pr 13,5 ul 1955 r 828.

SCARFONE, D. Jean Laplanche. Paris: Presses Universitaires de France, 1997.

SIBONY, D. Le féminin et la séduction. Paris: Grasset, 1986.

STENDHAL. De l'amour. Tome 1. Nova ed. "Oeuvres complètes". Genebra: Édito-Service, 1967.

TRAVERSES. L'ironie de la communauté. Séduction, n 17, Paris: Centre National d'art et de culture Georges Pompidou, nov., 1979. . La stratégie des apparences. Séduction, $\mathrm{n}^{\circ}$ 18, Paris: Centre National d'art et de culture Georges Pompidou, fev., 1980.

VAN der MAREN, J.-M. "Les savoirs et la recherche pour l'éducation". In: ROY, G.-R. (dir.). Contenus et impacts de la recherche universitaire actuelle en sciences de l'éducation. Actes du $2 e$ congrès des sciences de l'éducation de langue française du Canada. Tomo 3, L'enseignant et l'apprentissage (pp. 1.023-1.031). Sherbrooke: Éditions du CRP, Université de Sherbrooke, 1990.

WINKIN, Y. "Erving Goffman: Portrait du sociologue en jeune homme". In: GOFFMAN, E. Les moments et leurs hommes. Paris: Seuil/Minuit, 1988, pp. 13-91.

ZWEIG, S. Trois poètes de leur vie. Paris: Stock, 1937. 